\title{
Evaluation of Strawberry Cultivars for Growth and Yield Characteristics in Plain Region of Chattisgarh, India
}

\author{
Neetu* and Shishir Prakash Sharma \\ Department of Fruit Science, College of Agriculture, Indira Gandhi Krishi Vishwavidyalaya, \\ Raipur - 492 012, Chhattisgarh, India \\ *Corresponding author
}

\section{A B S T R A C T}

\begin{tabular}{|l|}
\hline Ke y w or d s \\
Evaluation, Growth, \\
Yield, Strawberry
\end{tabular}

A research trial was carried out in the experimental field of Pt. K.L.S. College of Horticulture, Rajnandgaon (C.G) during the year 2016-2017 to evaluate some strawberry cultivars in plain region of Chattisgarh to assess different cultivars of strawberry in plain region of Chattisgarh. Results revealed that Nabila produced higher vegetative growth (Plant height, number of leaves, plant spread and number of runners per plant) whereas the minimum vegetative growth in Rania. Earliest flowering and fruiting was exhibited by Camarosa and Nabila whereas Kamila was too late in flowering. Maximum number of flowers and fruits per plant was recorded in Nabila, Camarosa and Flaminia respectively. Largest and heaviest fruits were produced by Nabila but the diameter of fruits was highest of Kamila. The highest fruit yield per plant was produced by Nabila $(655.06 \mathrm{~g} / \mathrm{plant})$ followed by Camarosa and Kamila. Simultaneously Nabila exhibited lowest percentage of fruit spoilage under field condition whereas highest was in Camarosa. Nabila have economical profitable in respect of higher yield and lower spoilage percent.

\section{Introduction}

The cultivated strawberry (Fragaria $x$ ananassa Duch.) is one of the luscious and soft fruits of the world. It is a hybrid of two Native American species; Fragaria chiloensis and Fragaria virginiana, belongs to the Rosaceae family. All cultivated varieties are octaploid $(2 n=56)$. Botanically it is an aggregate fruit which is highly perishable in nature. In temperate climate condition, its plants behave like a small perennial herb (Finn and Strike, 2008) with shallow root system whereas in sub-tropical climate it behaves as annuals. Fruit of strawberry is a modified receptacle, one seeded fruit or achenes which is located on the outer surface (Szczesniak and Smith, 1969). Strawberry is non-climacteric fruit (Coombey, 1976) and fruits reach in full red stage within 28-30 days after anthesis, having the maximum fruit weight and size. Strawberry is grown throughout the world but the United States is the world's largest producer of strawberries, producing nearly 1.3 million metric tons in 2010 and accounting for 30 percent of the total world strawberry production (Morgan, 2012).

In Chhattisgarh strawberry cannot become very popular because of lack of knowledge. It is grown only in Ambikapur and Surajpur district with production $12.50 \mathrm{MT}$ and 
12.00MT respectively (ADH office balrampur, 2016). The continued introduction of strawberry cultivars to the market increases the need for reliable methods of identification and genetic diversity assessment (Degani et al., 2001) In Chhattisgarh strawberry is a new crop to farmers or growers and its cultivation practices are very specific to take commercially. Keeping these points in view the present investigation work was carried out in the field of Pt.K.LS College of Horticulture during 2016-2017 with the objective, Evaluation of Strawberry cultivars for vegetative growth and yield parameters.

\section{Materials and Methods}

The experiment was conducted at Horticulture Research Farm Pt. Kishori Lal Shukla College of Horticulture and Research station Rajnandgaon (C.G.) from October 2016 to March 2017. Geographically, it is located at $17^{\circ} 14^{\prime} \mathrm{N}-24^{\circ} 45^{\prime} \mathrm{N}$ latitude and $79^{\circ} 30^{\prime} \mathrm{E}$ $84^{\circ} 15^{\prime} \mathrm{E}$ longitude. Rajnandgaon situated on the bank of Shivnath and falls between $21^{\circ} 06^{\prime} \mathrm{N}$ latitude and $81^{\circ} 02^{\prime} \mathrm{E}$ longitude at an altitude of 307 meter above the mean sea level.

The experimental material comprised of 6 varieties of Strawberry viz., Nabila (T1), Rania (T2), Kamila (T3), Camarosa (T4), Flavia (T5) and Flaminia (T6)., were used as planting material. The sapling of all 6 varieties of Strawberry was planted in a randomized block design with four replications. The planting of experimental material was done on 20 October, 2016. Recommended fertilizer and other cultural package of practices were adopted for better crop growth.720 vigorous, healthy, free from diseases, insect-pest and well rooted propagation material were selected to planting for the experiment. All plants were kept with uniform cultural practices, i.e. Fertigation and irrigation. Five random competitive plants were selected from each plot and following observation were recorded. The average value of each observation was calculated on the basis of five plants for each cultivar in every replication.

Observations were recorded and growth and yield parameters of fruits on 5 randomly selected plants in each treatments. Average plant height and plant spread were recorded in centimeter with the help of meter scale. Day require for first flowering was recorded as the number of days taken from initiation of flowering. Average number of runners per plant was recorded by manual counting method. Average length of runners was recorded in centimeter. Day require for fruit set was recorded as the number of days taken from fruit set. Total number of fruits per plant, fruit length and breadth in centimeter were recorded. Average fruit weight in gram was computed and yield of fruit per plant was recorded. The yields per hectare in tons were recorded by yield per plant multiplied with total number of plant per hectare. Data pertaining to fruit size, fruit weight were recorded at each harvest and average was taken after completion of all harvests. These data were subjected to statistical analysis following standard procedures (Panse and Sukhatme, 1989).

\section{Results and Discussion}

The finding of the trial of different growth and yield parameters are presented under the following heads:

\section{Plant height (cm)}

A perusal of data (Table 1) revealed that the varieties differed significantly in respect of plant height. The maximum plant height was observed in Nabila (25.39) it was found statistically at par with Camarosa (23.21) and Flaminia (22.96), whereas minimum plant height was recorded in Rania (18.23). The 
reason for the variation in these cultivars could be that the genes responsible for the plant height did not express them fully with the same degree as it does at other places because of different agro-climatic conditions. Varietal differences in plant spread and height was also noted by Singh et al., (2008) in Meghalaya which supports the present observation.

\section{Number of leaves/plant}

The data presented in Table 1 showed that the number of leaves/plant varied significantly in different varieties. Nabila was observed to have maximum number (39.87) of leaves/plant, whereas Rania have minimum number (26.79).

Variation with respect to number of leaves could be attributed to the fact that different cultivars may react differently to photoperiod, light, temperature, nutrient status of soil, available metabolites and their allocation to the above ground plant parts (Tanaka and Muzuta, 1974; Strik, 1988).

\section{Plant spread (cm)}

Significant variation among the varieties was observed for plant spread (Table 1). The highest plant spread $(38.54 \mathrm{~cm})$ in East-West direction was recorded in the cultivar Nabila and the lowest $(24.73 \mathrm{~cm})$ in the cultivar Rania, whereas the highest plant spread (41.23 $\mathrm{cm})$ in North-South direction was recorded in the cultivar Nabila and the lowest $(18.10 \mathrm{~cm})$ in the cultivar Rania (Table 1).

It is evident from the data that plant spread was more in North-South direction in comparison to East-West. This may be due to the moisture fluctuations which was continuous in North-South directions. The above finding comes in accordance with the findings of Sharma et al., (2014)

\section{Number of runners/plant}

From the Table 1 it is obvious that significantly highest number of runners per plant were produced by Nabila (7.65) which was at par with Camarosa (5.20) and Flaminia (6.45), whereas Rania recorded lowest number (2.15) of runners per plant. Because of confined and short favorable agro-climatic conditions, reduced number of runners was produced by the plants. This result is at par with that of Kumar et al., (2011) in Sikkim condition and Baumann et al., (1993) in British Columbian condition.

\section{Length of runners (cm)}

The data presented in Table 1 showed that Nabila produced significantly longest (88.52) runners which were at par with Camarosa (86.25) and Flavia (85.92) and Flaminia (88.15). Shortest runners were recorded in Rania (44.70).

Irrigation by drip, which confined the moisture up to root zone had resulted in the smaller runners, because they (emerged runners) were not feasible to grow beyond the outskirts of moisture regime Kumar (2002).

\section{Flowering duration}

Significant variation among the varieties was observed for flowering duration (Table 2). Kamila cultivar recorded the maximum flowering duration (53days), while Camarosa recorded the minimum (41.37 days). The minimum days require for flowering in Camarosa (41.37) might be attributed to its short crop period as observations made by Montero et al., (1996).

Variability in flowering period in different varieties might also be due to differences in their chilling requirement as suggested by Joolka and Badiyala (1983) 
Table.1

\begin{tabular}{|c|c|c|c|c|c|c|}
\hline \multirow[t]{3}{*}{ Treatment } & Plant & Number of & & Plant & \multirow{3}{*}{$\begin{array}{l}\text { Number } \\
\text { of runners } \\
\text { /plant }\end{array}$} & \multirow{3}{*}{$\begin{array}{l}\text { Length of } \\
\text { runners / } \\
\text { plant }\end{array}$} \\
\hline & height & leaves/plant & \multicolumn{2}{|c|}{$\operatorname{spread}(\mathrm{cm})$} & & \\
\hline & $(\mathrm{cm})$ & & East- & North- & & \\
\hline & & & west & south & & \\
\hline $\mathrm{T} 1$ & 25.39 & 39.87 & 38.54 & 41.23 & 7.65 & 88.52 \\
\hline $\mathrm{T} 2$ & 18.23 & 26.79 & 24.73 & 28.18 & 2.15 & 44.70 \\
\hline T3 & 20.85 & 27.15 & 29.80 & 28.10 & 2.95 & 47.40 \\
\hline $\mathrm{T} 4$ & 23.21 & 32.22 & 36.46 & 39.89 & 5.20 & 86.25 \\
\hline $\mathrm{T} 5$ & 21.78 & 31.19 & 34.72 & 35.89 & 4.96 & 85.92 \\
\hline T6 & 22.96 & 34.01 & 32.49 & 35.81 & 6.45 & 88.15 \\
\hline SEm \pm & 0.99 & 1.07 & 1.54 & 1.54 & 0.85 & 7.35 \\
\hline $\mathrm{CD}$ at $5 \%$ & 3.03 & 3.2 & 4.68 & 4.68 & 2.60 & 22.36 \\
\hline
\end{tabular}

Table.2

\begin{tabular}{|c|c|c|c|c|c|c|}
\hline \multirow[t]{4}{*}{ Treatment } & Flowering & Number & Number & Fruit & Spoilage & Yield per \\
\hline & duration & of & of fruits & weight & fruit & plant (g) \\
\hline & & flowers/ & /plant & (g) & percent & \\
\hline & & plant & & & & \\
\hline $\mathrm{T} 1$ & 42.59 & 27.42 & 24.71 & 26.02 & 6.60 & 655.06 \\
\hline $\mathrm{T} 2$ & 46.65 & 22.62 & 18.84 & 14.85 & 6.72 & 280.36 \\
\hline $\mathrm{T} 3$ & 53.00 & 22.03 & 19.62 & 25.61 & 7.22 & 504.01 \\
\hline T4 & 41.37 & 26.18 & 23.10 & 22.43 & 9.10 & 520.88 \\
\hline T5 & 45.37 & 23.18 & 20.43 & 17.74 & 7.08 & 361.52 \\
\hline T6 & 46.87 & 24.5 & 20.53 & 22.25 & 8.45 & 456.41 \\
\hline SEm \pm & 1.07 & 1.05 & 0.97 & 1.87 & 0.22 & 56.62 \\
\hline $\mathrm{CD}$ at $5 \%$ & 3.28 & 3.21 & 2.95 & 5.70 & 0.69 & 172.33 \\
\hline
\end{tabular}

Number of flowers produced per plant

A perusal of data (Table 2) revealed that the varieties differed significantly in respect of their flower numbers. The maximum number of flowers produced per plant was observed in Nabila (27.42), while treatment Kamila (22.62) produced minimum number of 
flowers. The increment in the number of flowers may be due to more light intensity in the region. Increased number of flowers per plant was observed in all treatments over the reports of researchers (Jamal Uddin et al., 2016) of Bangladesh.

\section{Number of fruits/plant}

The data presented in Table 2 showed that the number of fruits/plant varied significantly in different varieties. Nabila was observed to have maximum number (24.71) of fruits/plant being at par with Camarosa (23.10), while Rania had the minimum (18.84) fruits/plant. Because of more flower production, fruits harvested per plant were also more. Similar result were found by Baumann et al., (1993) who were found that Tristar produce maximum fruits per plant (26.00) and Belakhud et al., (2015) were also found that Chandler produce maximum fruits per plant (28.23).

\section{Fruit weight (g)}

Table 1 was shown that the heaviest fruits were harvested from treatment Nabila (26.02) which was found statistically at par with Kamila (25.61) and Camarosa (22.43) and Flaminia (22.25). The lightest fruits were produced by Rania (14.85). According to Morgan (2006), the final size and shape of the berry depend on the number of achenes formed, which is determined by pollination and fertilization during blooming.

\section{Spoilage of fruit per plant (\%)}

A perusal of data (Table 2) revealed that the varieties differed significantly in respect of their spoilage percent of fruits. Minimum percent spoilage of fruit per plant was found in Nabila (6.60) followed by Rania (6.72), Flavia (7.08) and Kamila (7.22). Camarosa (9.10) has maximum spoilage percent of fruits. This was in the level of Kumar (2002) who reported on spoilage of 8.71 per cent in the Cultivar Red Coat. Spoilage of fruits was observed in the form of eating by the birds, insects and microbial rotting under field condition.

\section{Yield per plant $(g)$}

The greatest amount of yield (655.06 g/plant) was produced Nabila cultivar which was at par with Camarosa (520.88) and Kamila (504.01) (Table 2). Rania gave the lowest yield (280.36) per plant followed by Flavia (361.52). This was due to the maximum flowering and fruits with greater weight. The result are accordance with finding of Belakhud et al., (2015) who reported that the maximum fruit yield per plant in Chandler $(616 \mathrm{~g})$ whereas the minimum fruit yield per plant was reported in Addie (90g).

Considering the above results it can be concluded that Nabila cultivar gave maximum vegetative growth, bears the maximum flowers and fruits. The fruit weight, fruit length of fruit were also found maximum in Nabila and might be an appropriate commercial strawberry cultivar for plain region of Chhattishgarh.

\section{References}

Baumann, T.E., Eaton G.W. and Spaner D. (1993) Yield Components of Dayneutral and Short-day Strawberry Varieties on Raised Beds in British Columbia. Hort. Science 28(9):891-894.

Belakhud, B., Bahadur, V. and Prasad, V.M. (2015) Performance of strawberry (Fragaria $x$ ananassa Duch.) varieties for yield and biochemical parameters. Pharma Innovation Journal; 4(10): 0508.

Coombey (1976). The development of fruits. Ann. Rev. Plant Physiol., 27: 507-512. 
Degani C, Rowland LJ, Saunders JA, Hokanson SC, Ogden EL, GolanGoldhirst A et al., A comparison of genetic relationship measures in strawberry (Fragaria $\mathrm{x}$ ananassa Duch.) based on AFLP, RAPDs, and pedigree data. Euphytica 2001; 117:1-12.

Finn, C.E. and Strik, B.C. (2008). Strawberry cultivars for Oregon, EC 1618-E, Oregon State University, pp. 1-7.

Jamal Uddin, A.F.M., Ahsan M.K., Hussain M.S., Mahmud M.F. and Mehraj, H. (2016). Evaluation of Strawberry Germplasm at Sher-E-Bangla Agricultural University, Bangladesh World Applied Sciences Journal 34 (1): 78-83.

Joolka, N.K. and Badiyala, S.D. (1983). Studies on the comparative performance of strawberry cultivars. Haryana $J$. of Hort. Sci. 12(3-4): 173-177.

Kumar, A., Avasthe, R.K., Pandey, B. K., Ramesh, D.R. and Rahman, H. (2011).Varietal Screening of Strawberry (Fragaria x ananassa Duch.) under Organic Production System for Fruit Quality and yield in Mid-Hills of Sikkim Himalayas, Indian J. Plant Genet. Resour. 24(2): 243-245.

Kumar, R. 2002.Studies on the performance of some strawberry (Fragaria ananassa L.) cultivars. M.Sc. (Ag) Thesis, Indira Gandhi Krishi Vishwavidyalaya, Raipur.p.27-64.

Morgan, L. (2006). Hydroponic strawberry production. A technical guide to the hydroponic production of strawberries. Suntec (NZ) Ltd., Tokomaru, New Zealand, pp: 43-69.

Panse VG, Sukhatme PV. Statistical Methods for Agricultural Workers. Indian Council of Agricultural Research, New Delhi, 1969.

Sharma G. Yadav A. and Thakur M. (2014) Studies on Growth and Flowering Attributes of Different Strawberry Cultivars (Fragaria $\mathrm{x}$ ananassa Duch.) in Himachal Pradesh. Asian J. of $A d v$. Basic Sci.: 3(1), 1-4.

Singh, A., Patel, R.K., De, L.C. and Periera, L.S. (2008). Performance of strawberry cultivars under sub-tropics of Meghalaya. Indian J. Agric. Sci., 78 (7): 1-4.

Strik B. C. (1988) Photosynthesis, yield component analysis, and growth analysis of strawberry. DissertationAbstracts-International, B-Sciencesand-Engineering, 48(8), 2175.

Szczesniak, A.S. and Smith, B.J. (1969). Observation on strawberry texture, a three prolonged approach. J. Textural Studies, 1: 65-68.

Tanaka, Y. and Mizuta, M. (1974). Nutritional - physiological studies on strawberry cv. Hokowase in long term cultivation. I. Influence of nitrogen on growth, yield and absorption of nutrients. Bul. Nara Agri. Expt. Sta 6:38-43.

\section{How to cite this article:}

Neetu and Shishir Prakash Sharma. 2018. Evaluation of Strawberry Cultivars for Growth and Yield Characteristics in Plain Region of Chattisgarh, India. Int.J.Curr.Microbiol.App.Sci. 7(02): 2835-2840. doi: https://doi.org/10.20546/ijcmas.2018.702.345 